TEORETSKI I METODOLOŠKI ASPEKT OPTIMIZACIJE ODNOSA EKONOMSKOG POTENCIJALA I IZVORA ZA NAMIRIVANJE JAVNIH POTREBA

\title{
THEORETICAL AND METHODOLOGICAL ASPECTS OF OPTIMIZATION OF RELATIONSHIP BETWEEN ECONOMIC POTENTIAL AND SOURCES FOR PUBLIC NEEDS SETTLEMENT
}

\author{
Aleksandar Stojanović \\ Univerzitet u Istočnom Sarajevu, Ekonomski fakultet Pale, Bosna i Hercegovina \\ University of East Sarajevo, Faculty of Economy Pale, Bosnia and Herzegovina
}

\section{REZIME}

Relativni nivo fiskalnih prihoda $u$ odnosu na ukupni agregat društvenog proizvoda ili nacionalnog dohotka, središnji je pokazatelj koji treba utvrditi u nacionalnoj ekonomiji. Taj pokazatelj je "taks racio". Težnja gotovo svake ekonomske, a posebno fiskalne politike, je da taj pokazatelj izražava optimalni odnos između onog dijela društvenog proizvoda ili nacionalnog dohotka koji se namjerava upotrebiti za namirivanje javnih potreba i samog opšteg agregata ovih potonjih ekonomskih kategorija. Posebno je njegov značaj u osmišljavanju koncepcije srednjoročnog ili pak dugoročnog društveno $\neg$ ekonomskog razvoja. Potrebno je odrediti i okvire globalne raspodele društvenog proizvoda ili nacionalnog dohotka, prihvatljive, na jednoj strani, sa stajališta uravnoteženog $i$ stabilnog ekonomskog rasta, a s druge strane, sa stajališta uravnoteženih interesa svih socijalnih struktura savremenih miješovitih društava.

Ključne riječi: javne finansije, fiskalno opterećenje, tax racio.

\section{UVOD}

Valja zaključiti i to da se utvrđivanje "taks racia" ubraja u onaj krug aktivnosti društva kojim se definišu okviri raspodjele društvenog proizvoda i nacionalnog dohotka na temeljne vrijednosne namjene: ličnu potrošnju, investicionu potrošnju i javnu potrošnju. Takva se raspodjela ukupnog rezultata društvenog rada

\section{SUMMARY}

The relative level of fiscal revenue in relation to the total aggregate domestic product or national income is a central indicator to be established in the national economy. This indicator is the "tax ratio". The tendency of almost every economic and especially fiscal policy is that this indicator expresses the optimal ratio between the part of the domestic product or national income, which is intended to be used for the settlement of public needs and the general economic aggregate of the latter economic categories. Its special importance lies in the design concept of medium-term or long-term social and economic development. It is necessary to determine the framework of the global distribution of the domestic product or national income, which is acceptable, on the one hand, from the perspective of a balanced and stable economic growth, and on the other hand, from the standpoint of balancing interests of all social structures of modern mixed societies.

Keywords: Public finance, Fiscal Load, Tax Racio.

\section{INTRODUCTION}

It should be also concluded that the determination of "tax ratio" belongs to the activities of the society that defines the frames of distribution of the domestic product and national income into fundamental valuation purposes: personal consumption, investment spending and public consumption. Such a distribution 
(tj. društvenog proizvoda) može ostvarivati pomoću dva kriterija: tržišnog i planskog. Prvi kriterij je svojstven otvorenim tržišnim modelima ekonomije, a drugi bivšim modelima socijalističkih ekonomija. Ne treba zaključiti da je determinisanje opisane globalne raspodjele društvenog proizvoda prepušteno stihiji djelovanja zakonitosti ponude i potražnje na slobodnom tržištu. Ta je stihijnost odavno uočena i postepeno sputavana raznoraznim načinima i metodama (političkim, ekonomskim i dr). Vrhunac obuzdavanja takve stihijnosti slobodnog djelovanja tržišnih odnosa bila je pojava intervencionističke države XX vijeka ili još poznatija kao "državni kapitalizam". $\mathrm{Na}$ drugoj strani, radikalno obuzdavanje slobode tržišta bilo je utjelovljeno u pojavi socijalističke države. Pažnju u prvom redu privlači utvrđivanje onog dijela društvenog proizvoda ili nacionalnog dohotka, koji je potreban za namirivanje javnih potreba. Relativna vrijednost spomenutog "taks racia" korespondira nivou ekonomske razvijenosti dotične ekonomije, mjerene visinom "per kapita" nacionalnog dohotka ili društvenog proizvoda. Relativna vrijednost tog pokazatelja zavisi od visine nacionalnog dohotka ili fiskalnom kapacitetu nacionalne ekonomije. Zato od nivoa ekonomske razvijenosti zavisi $\mathrm{i}$ visina fiskalnog kapaciteta, tj. mogućnosti oporezivanja. To je relativno pojednostavljeni zaključak, budući da su ti odnosi međusobno daleko složeniji. Te karakteristike i globalne međuovisnosti omogućavaju pretpostavljanje vrijednosti "tax racia" za svaku ekonomiju. Pri tome se moraju, naravno, uzeti u obzir i drugi ekonomski faktori koji djeluju na fiskalni kapacitet odnosno na sposobnost poreskog opterećenja. Ta dva parametra, aktuelni dohodak po glavi stanovnika i mogućnost prognoze njegove relativne vrijednosti, omogućavaju izračunavanje indeksa fiskalnog tereta. Dijeljenjem "taks racia" i pretpostavljenog relativnog pokazatelja dobije se "taks efort" (tax effort) . Neke dosadašnje analize, pokazale su da nacionalne ekonomije s višim "taks raciom" od prosječne njegove vrijednosti, bilježile su u pravilu i veći "taks efort" od jedi- of the total score of social work (i.e. domestic product) may be exercised using two criteria: the market and the planning one. The former criterion is characteristic of open market economy models, and the latter to models of the former socialist economies. One should not conclude that the determination of the above described global distribution of the domestic product is left to elemental action of the laws of supply and demand on the free market. This elemental force has long been observed, and gradually hampered by various ways and methods (political, economic, etc.). The peak of taming such destructive effects of free market relations was the emergence of the interventionist state in XX century or more commonly known as "state capitalism". On the other hand, radical taming of the market was embodied in appearance of a socialist state. Attention is primarily attracted to the determination of the part of the domestic product or national income, which is required for the settlement of public needs. The relative value of the said "tax ratio" corresponds to the level of economic development of the respective economies measured by the height of "per capita" of national income and domestic product. The relative value of this indicator depends on the level of national income or the fiscal capacity of the national economy. Therefore, the height of fiscal capacity depends on the level of economic development, i.e. taxation ability. This is a relatively simplified conclusion, since those relations with each other are far more complex. These features and global interdependence allow assuming the value of "tax ratio" for each economy. Therefore, other economic factors that influence the fiscal capacity and the ability of the tax burden must, of course, be taken into account. These two parameters, the current per capita income and the ability to forecast its relative value, enable the calculation of the fiscal burden index. Dividing "tax ratio" and assumed relative indicator gives "tax effort". Some previous analyses have shown that the national economy with "tax ratio" higher than its average value generally recorded "tax effort" higher than the unit. Interpretation and 
niče. Interpretacija, a još više korištenje tog indeksa u ekonomsko-fiskalnoj politici zahtijeva dodatna saznanja i pokazatelje.

Brojne su analize i stavovi o fiskalnom opterećenju u Bosni i Hercegovini, koji su dijametralno suprotni i kao takvi izazivaju zbunjenost javnosti. Nosioci poreske vlasti prednjače u stavovima da su u $\mathrm{BiH}$ građani i privreda najmanje opterećeni u regionu, a da je BiH kao takva „najprivlačnija za strane direktne investicije“. Pri tome se, namjerno ili slučajno daju djelimično tačni ili pogrešni podaci tipa: „stopa PDV od $17 \%$ je najniža u regionu“, a ne kaže se da sve ostale zemlje imaju pored opšte po jednu ili više sniženih stopa PDV na osnovne životne potrepštine (tako su npr. lijekovi sa pozitivne liste u Srbiji i do 3 puta jefitniji). Ili, ,imamo najniže poreske stope na plate - samo $10 \%$ ", a da se ne kaže da su te plate istovremeno opterećenje najvišim stopama doprinosa za obavezno socijalno osiguranje, da preduzeća plaćaju brojne parafiskalitete iz svoje dobiti, pored poreza na dobit, itd.

Jedno od ključnih pitanja koje se postavlja u savremenom svijetu svakako je pitanje visine učešća javnih rashoda, odnosno javnih prihoda, u ukupnoj novostvorenoj vrijednosti (narodnom dohotku, odnosno društvenom proizvodu) neke zemlje u toku jedne kalendarske godine.

Odavno je uočeno da je za realizaciju zdravih i efikasnih međunarodnih ekonomskih odnosa izuzetno važno poznavati stepen fiskalnog opterećenja u sopstvenoj zemlji i u zemljama s kojima se sarađuje. Zbog toga nije iznenađujuće da su mnoge respektabilne međunarodne organizacije pristupile sačinjavanju odgovarajućih, za većinu zemalja prihvatljivih i uporedivih klasifikacija javnih prihoda. Među četiri u svijetu postojeće klasifikacije javnih prihoda najprihvatljivija je i u najvećoj upotrebi klasifikacija OECD. Osim nje, kao što će se videti nešto kasnije, u upotrebi su još i klasifikacija Ujedinjenih nacija pod nazivom Sistem nacionalnih računa, Evropski sistem integrisanih ekonomskih računa i klasifikacija Međunarodnog monetarnog fonda. further use of the index in the economic and fiscal policy requires additional research and indicators.

There are numerous analyses and views on the fiscal burden in Bosnia and Herzegovina, which are diametrically opposed and as such cause public confusion. Tax authorities mostly advocate that $\mathrm{BiH}$ citizens and businesses are least burdened in the region and that Bosnia and Herzegovina as such is "the most attractive for foreign direct investment". In doing so, they intentionally or accidentally give partially correct or wrong data such as: "VAT rate of $17 \%$ is the lowest in the region" but they do not say that all other countries have the general and one or more reduced VAT rates on basic life necessities (so, for example, medicines from the positive list in Serbia are to 3 times cheaper). Or, "we have the lowest tax rates on wages - only $10 \%$ ", but they do not say that the wages are burdened by the highest rates of contributions for compulsory social insurance, that many companies pay parafiscalities from their profits, in addition to income taxes, etc.

One of the key issues raised in the modern world is the question of the amount of the share of public expenditure or public revenue, in the total newly created value (national income, i.e. domestic product) of a country in a calendar year.

It has long been observed that the realization of sound and effective international economic relations requires the knowledge of the degree of fiscal burden in one's own country and in the countries with which it cooperates. It is therefore not surprising that many respectable international organizations joined the drafting of appropriate comparable classification of public revenues acceptable for most countries. Among the world's four existing classifications of public revenues the most acceptable and greatly used is the OECD Classification. In addition to it, as it can be seen below, the classification of the United Nations called SNA - System of National Accounts, ESA - European System of Accounts and IMF Classification are used. 
Osim toga, u upotrebi je, u najvećem broju zemalja svijeta, i prihvatljiva metodologija utvrđivanja bruto domaćeg proizvoda prema tržišnim cijenama (GDP).

$\mathrm{Na} z ̌ a l o s t$, ko nas nijedna vlast do sada nije naručila istraživanje po kojoj bismo mogli znati koliko je stvarno (efektivno) poresko opterećenje privrede i stanovništva, koliki je poreski kapacitet domaće ekonomijei shodno tome smiju li se javno-pravna tijela dalje zaduživati. Ako nemamo poreski kapacitet, taj dug moći će se vraćati samo prodajom državne imovine (kao što to danas rade Grci). Stoga nam je cilj da u ovome radu bar približimo pojmove stvarnog poreskog opterećenja i poreskog kapaciteta.

\section{FISKALNO OPTEREĆENJE - KOMPARATIVNA ANLIZA}

Ekonomske posljedice do kojih dolazi usljed postojećih visokih i diferenciranih poreskih opterećenja, dosadašnja teorijska emirijska istraživanja ukazuju na sljedeće (Dautbašic, 2014, str. 217): 1) Smanjuje se ponuda faktora proizvodnje, prije svega radne snage, što smanjuje privredni rast.; 2) Deformiše se vremenski raspored štednje i time uvećanje kapitala sposobnog za investicije i razvoj; 3) Među preduzećima i sektorima nastaju razlike u odnosu na način finansiranja i pravni oblik organizovanja i funkcionisanja poslovne djetanosti; 4) usljed visokog poreskog opterećenja privreda se seli u zone sa niskim fisklanim opterećenjem ili „bježe" u neformalni sektor, čime se smanjuje broj poreskih obveznika i poreski prihodi države. Time se ulazi u svojevrsnu spiralu - povećanje nezaposlenosti prouzrokuje dalje povećanje fisklanog opterećenja na preostale zaposlene u formalnom sektoru.

S druge strane, prenisko fisklano opterećenje, najčešće kao rezultat poreske konkurencije između zemalja sa ciljem privlačenje stranih direktnih investicija, može dovesti do nestabilnosti i nepredvidivosti punjenja budžeta. S toga je traženje prave mjere fiskalnog opterećenja imperativ uspješne fiskalne politike.
In addition, an acceptable methodology for determining the gross domestic product at market prices is used in most countries of the world (GDP).

Unfortunately, no government of ours has commissioned a study by which they could know how much the real (effective) tax burden on the economy and population is, what the tax capacity of domestic economy is, and consequently if public-legal bodies may continue to borrow. If we do not have tax capacity, such debt will be repaid only by selling state property (as Greece is doing today). Therefore, the goal of this paper is to at least clarify the terms of actual tax burden and tax capacity.

\section{FISCAL LOAD - COMPARATIVE ANALYSIS}

Economic consequences that occur due to the existing high and differentiated tax burdens, previous empyric theoretical studies suggest the following (Dautbašic, 2014, p. 217): (1) The supply of factors of production is reduced, especially labor force, which reduces economic growth; (2) Saving timetable is deformed including a capital increase suitable for investment and development; (3) Differences arise among the companies and sectors in relation to the financing and legal form of organization and functioning of the business sectors; (4) Due to the high tax burden, the economy is moving in the zones with low fiscal load or "flee" into the informal sector, thereby reducing the number of tax payers and tax revenue for the state. This leads to a spiral - rising unemployment causes a further increase in fiscal load on the remaining employees in the formal sector.

On the other hand, too low fiscal load, mainly as a result of tax competition between countries with the aim of attracting foreign direct investment, can lead to instability and unpredictability of filling the budget. Therefore, the search for genuine measures of fiscal load is imperative for successful fiscal policy. 
Posmatrano na makro planu (opšte stanovište), princip umjerenosti oporezivanja podrazumijeva utvrđivanje tzv. apsolutnog poreskog limita, odnosno poreskog opterećenja društvenog proizvoda pri kojem dalje povećanje poreskih stopa, ili uvođenje novih poreskih oblika, više ne bi uvećavalo poreske prihode države. Štaviše, ukoliko poreski teret pređe apsolutni poreski limit, svako dalje povećanje poreza dovodi do smanjenja poreskih prihoda.

Nosioci poreske politike moraju voditi računa da poresko opterećenje bude umjereno, jer bi u su-protnom poreska politika mogla doći u koliziju sa izdašnošću poreskog sistema, ali i s ekonomskom efikasnošću. Za realizaciju zdravih i efikasnih međunarodnih ekonomskih odnosa izuzetno važno poznavati stepen fiskalnog opterećenja u sopstvenoj zemlji i u zemljama s kojima se sarađuje. Zbog toga nije iznenađujuće da su mnoge respektabilne međunarodne organizacije pristupile sačinjavanju odgovarajućih, za većinu zemalja prihvatljivih i uporedivih klasifikacija javnih prihoda. Među četiri u svijetu postojeće klasifikacije javnih prihoda najprihvatljivija je i u najvećoj upotrebi klasifikacija OECD. Osim nje, kao što će se vidjeti nešto kasnije, u upotrebi su još i klasifikacija Ujedinjenih nacija pod nazivom Sistem nacionalnih računa, Evropski sistem integrisanih ekonomskih računa i klasifikacija Međunarodnog monetarnog fonda (Stojanović i Raičević, 2013, str. 29).

Osim toga, u upotrebi je, u najvećem broju zemalja svijeta, i prihvatljiva metodologija utvrđivanja bruto domaćeg proizvoda prema tržišnim cijenama (GDP).

U tabeli koja je navedena niže u tekstu daje se nivo fiskalnog opterećenja za jedan broj zemalja članica OECD-a i za odabrane godine čitavog posmatranog perioda od 1965. godine. Takođe, autor je učinio napor, pa je na bazi svojih istraživanja, prikazao fiskalno opterećenje u Bosni i Hercegovini. Naravno, podaci za BiH nisu do kraja uporedivi sa onima za navedene zemlje članice OECD-a, posebno što se godinama razlikovao obračun društvenog proizvoda u $\mathrm{BiH}$ od onoga koji je u primjeni u zemljama OECD-a (Ibidem).
Viewed in macro terms (general view), the principle of tax temperance means setting out the so-called absolute tax limit, or tax load of domestic product where further increase of tax rates or introducing new tax forms would increase the tax revenue of the state. Furthermore, in case the tax load exceeds the absolute tax limit, any further increase of tax would lead to a decrease of tax revenue.

The tax policy holders must take into account that the tax load must be moderate, otherwise the tax policy might collide not only with the tax system abundance but with economic cost-effectiveness as well. For the realization of healthy and effective international economic relations it is extremely important to know the degree of fiscal burden in one's own country and in countries with which one cooperates. It is therefore not surprising that many respectable international organizations joined the drafting of comparable classification of public revenues appropriate and acceptable for most countries. Among the world's four existing classification of public revenues the most acceptable and widely used is OECD Classification. In addition to it, as you will see a bit later, there are also in use the classification of the United Nations called the System of National Accounts (SNA), the European System of Accounts (ESA) and IMF Classification (Stojanović i Raičević, 2013, str. 29).

In addition, an acceptable methodology for determining the gross domestic product at market prices is used in most countries of the world (GDP).

The table set forth below provides the level of fiscal burden for a number of OECD member countries and selected years of the entire observed period since 1965. Also, the author has made an effort, and based on his research, presented the fiscal burden in Bosnia and Herzegovina. Of course, the data for $\mathrm{BiH}$ are not fully comparable with those for OECD member countries, especially as the calculation of the domestic product in $\mathrm{BiH}$ has been differently applied than in OECD countries (Ibidem). 
Tabela1

Fiskalno opterećenje u zemljama OECD-a i u BiH Fiscal load in OECD countries and BiH

\begin{tabular}{|c|c|c|c|c|c|c|c|c|}
\hline $\begin{array}{c}\text { Zemlje } \\
{[\text { Country }]}\end{array}$ & 2005 & 2006 & 2007 & 2008 & 2009 & 2010 & 2011 & 2012 \\
\hline $\begin{array}{l}\text { Australija } \\
\text { [Australia] }\end{array}$ & 30,0 & 29,6 & 29,7 & 27,1 & 25,8 & 25,6 & 26,5 &.. \\
\hline $\begin{array}{l}\text { Austrija } \\
\text { [Austria] }\end{array}$ & 42,1 & 41,5 & 41,8 & 42,8 & 42,4 & 42,2 & 42,3 & 43,2 \\
\hline $\begin{array}{l}\text { Belgija } \\
\text { [Belgium] }\end{array}$ & 44,5 & 44,1 & 43,6 & 44,0 & 43,1 & 43,5 & 44,1 & 45,3 \\
\hline $\begin{array}{l}\text { Kanada } \\
\text { [Canada }]\end{array}$ & 32,3 & 32,6 & 32,3 & 31,6 & 31,4 & 30,6 & 30,4 & 30,7 \\
\hline $\begin{array}{l}\text { Čile } \\
{[\text { Chile] }}\end{array}$ & 20,7 & 22,0 & 22,8 & 21,4 & 17,2 & 19,5 & 21,2 & 20,8 \\
\hline $\begin{array}{l}\text { Češka Republika } \\
\text { [Czech Republic] }\end{array}$ & 36,1 & 35,6 & 35,9 & 35,0 & 33,8 & 33,9 & 34,9 & 35,5 \\
\hline $\begin{array}{l}\text { Danska } \\
\text { [Denmark] }\end{array}$ & 50,8 & 49,6 & 48,9 & 47,8 & 47,8 & 47,4 & 47,7 & 48,0 \\
\hline $\begin{array}{l}\text { Estonija } \\
\text { [Estonia] }\end{array}$ & 30,6 & 30,7 & 31,4 & 31,9 & 35,3 & 34,0 & 32,3 & 32,5 \\
\hline $\begin{array}{l}\text { Finska } \\
\text { [Finland] }\end{array}$ & 43,9 & 43,8 & 43,0 & 42,9 & 42,8 & 42,5 & 43,7 & 44,1 \\
\hline $\begin{array}{l}\text { Francuska } \\
\text { [France] }\end{array}$ & 44,1 & 44,4 & 43,7 & 43,5 & 42,5 & 42,9 & 44,1 & 45,3 \\
\hline $\begin{array}{l}\text { Njemačka } \\
\text { [Germany] }\end{array}$ & 35,0 & 35,7 & 36,1 & 36,5 & 37,4 & 36,2 & 36,9 & 37,6 \\
\hline $\begin{array}{l}\text { Grčka } \\
\text { [Greece] }\end{array}$ & 32,1 & 31,6 & 32,5 & 32,1 & 30,5 & 31,6 & 32,2 & 33,8 \\
\hline $\begin{array}{l}\text { Mađarska } \\
\text { [Hungary] }\end{array}$ & 37,3 & 37,3 & 40,3 & 40,1 & 39,9 & 38,0 & 37,1 & 38,9 \\
\hline $\begin{array}{l}\text { Island } \\
\text { [Iceland] }\end{array}$ & 40,7 & 41,5 & 40,6 & 36,7 & 33,9 & 35,2 & 36,0 & 37,2 \\
\hline $\begin{array}{l}\text { Irska } \\
\text { [Ireland] }\end{array}$ & 30,1 & 31,6 & 31,1 & 29,2 & 27,6 & 27,4 & 27,9 & 28,3 \\
\hline $\begin{array}{l}\text { Izrael } \\
\text { [Israel] }\end{array}$ & 35,7 & 36,0 & 36,4 & 33,8 & 31,3 & 32,4 & 32,6 & 31,6 \\
\hline $\begin{array}{l}\text { Italija } \\
\text { [Italy] }\end{array}$ & 40,6 & 42,1 & 43,2 & 43,0 & 43,4 & 43,0 & 43,0 & 44,4 \\
\hline $\begin{array}{l}\text { Japan } \\
\text { [Japan] }\end{array}$ & 27,3 & 28,1 & 28,5 & 28,5 & 27,0 & 27,6 & 28,6 &.. \\
\hline $\begin{array}{l}\text { Koreja } \\
\text { [Corea] }\end{array}$ & 24,0 & 25,0 & 26,5 & 26,5 & 25,5 & 25,1 & 25,9 & 26,8 \\
\hline $\begin{array}{l}\text { Luksemburg } \\
\text { [Luxemburg] }\end{array}$ & 37,6 & 35,9 & 35,6 & 37,3 & 39,0 & 37,3 & 37,0 & 37,8 \\
\hline $\begin{array}{l}\text { Meksiko } \\
{[\text { Mexico] }}\end{array}$ & 18,1 & 18,2 & 17,7 & 20,9 & 17,4 & 18,9 & 19,7 &.. \\
\hline $\begin{array}{l}\text { Holandija } \\
\text { [Netherlands] }\end{array}$ & 38,4 & 39,1 & 38,7 & 39,2 & 38,2 & 38,9 & 38,6 &.. \\
\hline $\begin{array}{l}\text { Novi Zeland } \\
\text { [New Zealand] }\end{array}$ & 36,4 & 35,7 & 34,5 & 33,6 & 31,1 & 31,1 & 31,5 & 32,9 \\
\hline
\end{tabular}

Napomena: Tabela 1 se nstavlja na sljedećoj strani

Note: Table 1 continued on next page 


\begin{tabular}{lcccccccc}
\hline $\begin{array}{l}\text { Norveška } \\
\text { [Norway] }\end{array}$ & 43,2 & 43,5 & 42,9 & 42,1 & 42,0 & 42,6 & 42,5 & 42,2 \\
\hline $\begin{array}{l}\text { Poljska } \\
\text { [Poland] }\end{array}$ & 33,0 & 34,0 & 34,8 & 34,2 & 31,7 & 31,7 & 32,3 &.$\cdot$ \\
\hline $\begin{array}{l}\text { Portugal } \\
\text { [Portugal] }\end{array}$ & 31,1 & 31,8 & 32,5 & 32,5 & 30,7 & 31,2 & 33,0 & 32,5 \\
\hline $\begin{array}{l}\text { Slovačka Republika } \\
\text { [Slovac Republic] }\end{array}$ & 31,5 & 29,4 & 29,5 & 29,5 & 29,1 & 28,3 & 28,7 & 28,5 \\
\hline $\begin{array}{l}\text { Slovenija } \\
\text { [Slovenia] }\end{array}$ & 38,6 & 38,3 & 37,7 & 37,1 & 37,0 & 38,1 & 37,1 & 37,4 \\
\hline $\begin{array}{l}\text { Šnanija } \\
\text { [Spain] }\end{array}$ & 36,0 & 36,9 & 37,3 & 33,1 & 30,9 & 32,5 & 32,2 & 32,9 \\
\hline $\begin{array}{l}\text { Švedska } \\
\text { [Sweden] }\end{array}$ & 48,9 & 48,3 & 47,4 & 46,4 & 46,6 & 45,4 & 44,2 & 44,3 \\
\hline $\begin{array}{l}\text { Švajcarska } \\
\text { [Swisserland] }\end{array}$ & 28,1 & 27,9 & 27,7 & 28,1 & 28,7 & 28,1 & 28,6 & 28,2 \\
\hline $\begin{array}{l}\text { Turska } \\
\text { [Turkey] }\end{array}$ & 24,3 & 24,5 & 24,1 & 24,2 & 24,6 & 26,2 & 27,8 & 27,7 \\
\hline $\begin{array}{l}\text { Ujedinjeno Kraljevstvo } \\
\text { [United Kingdom] }\end{array}$ & 35,4 & 36,3 & 35,7 & 35,8 & 34,2 & 34,9 & 35,7 & 35,2 \\
\hline $\begin{array}{l}\text { Sjedinjene Američke Države } \\
\text { [United States of America] }\end{array}$ & 26,0 & 26,8 & 26,9 & 25,4 & 23,3 & 23,8 & 24,0 & 24,3 \\
\hline $\begin{array}{l}\text { OECD - Ukupno } \\
\text { [OECD - Total] }\end{array}$ & 34,8 & 35,0 & 35,0 & 34,5 & 33,6 & 33,8 & 34,1 &.. \\
\hline $\begin{array}{l}\text { Bosna i Hercegovina } \\
\text { [Bosnia and Herzegovina] }\end{array}$ & 43,1 & - & - & - & - & - & - & 48,0 \\
\hline
\end{tabular}

Izvor: OECD, 2014 - Za fiskalno opterećenje zemlja OECD-a; Za BiH su date procjene autora, budući da ne postoje zvanični vjerodostojni podaci.

Navedena tabela prikazuje fiskalno opterećenje u četiri decenije dugom periodu za jedan broj zemalja OECD-a i za BiH. Zapravo, tabela prikazuje učešće naplaćenih javnih prihoda fiskalnog (dažbinskog) tipa u bruto društvenom proizvodu po tekućim cijenama. Osnovni smisao navedenih podataka je da se: (1) utvrdi fiskalno opterećenje, (2) uoče tendencije promjena, (3) koliko-toliko izvrši upoređenje fiskalnog opterećenja u $\mathrm{BiH}$ i fiskalnog opterećenja u zemljama OECD-a, posebno sa aspekta promjena i (4) neutrališu metodološki nesporazumi oko valjanosti ovog pokazatelja.

Valja primijetiti da nije mali broj zemalja u kojima je udio javnih prihoda u društvenom proizvodu blizu, ili čak i iznad, 50\%. To su najrazvijenije zemlje ne samo Evrope već i svijeta (izuzetak su SAD i Japan) u kojima je uz to veoma prisutna i razvijena država blagostanja s jakim sektorom javnih dobara
Source: OECD, 2014 - For the fiscal burden of OECD countrys. For $\mathrm{BiH}$, the assessments are given by the author, since there are no official authentic data.

The table shows the fiscal burden in the four decades long period for a number of OECD countries and $\mathrm{BiH}$. In fact, the table shows the share of collected public revenues of the fiscal type in the gross domestic product at current prices. The basic purpose of these data is to: (1) determine the fiscal burden, (2) detect trends change, (3) more or less make a comparison of the fiscal burden in $\mathrm{BiH}$ with OECD countries, particularly in terms of changes and (4) neutralize methodological disagreements over the validity of this indicator.

It should be noted that there is not a small number of countries where the share of public revenue in GDP is close to, or even above $50 \%$. These are the most developed countries, not only of Europe but also the world (excluding USA and Japan) in which there exist a developed welfare state with a strong public 
i usluga. Visok udio javnog sektora u navedenim zemljama pokazuje da tržišni mehanizam nije u stanju da uvijek ostvari sve ekonomske funkcije i da je nužno prisustvo javnog sektora.

Iza različitih brojki kriju se različita objašnjenja, političke, ekonomske, kao i socijalne i druge prirode. U Japanu, Južnoj Koreji i u $\mathrm{SAD}$, na primjer, u realizaciji socijalne sigurnosti zaposlenih, ali i ukupnog stanovništva, značajnu ulogu imaju privatne korporacije, pa je nivo fiskalnog opterećenja u ovim trima ekonomski veoma snažnim državama relativno skroman. Nasuprot tome, jedna Švedska, odnosno jedna Danska, ekonomski, takođe, moćne zemlje, s dugom tradicijom izdašne socijalne zaštite zaposlenih i ukupnog stanovništva preko javnog sektora, imaju veoma visoko fiskalno opterećenje. ${ }^{1}$

Fiskalno opterećenje (posebno relativno, ili efektivno) u BiH veoma je visoko, nezavisno od manjkavosti njegovog poređenja sa zemljama OECD-a. Ono je rezultat, između ostalog, i činjenice da su mjesto i uloga države u zadovoljavanju javnih potreba (tzv. opšta i zajednička potrošnja) u BiH, kao jednoj od socijalističkih zemalja, bili dominantniji nego u većini zemalja tržišne orijentacije. Valja napomenuti da nivo fiskalnog opterećenja nije bio u skladu ni sa tadašnjom, u odnosu na sadašnje stanje značajnijom, ekonomskom snagom $\mathrm{BiH}$. $\mathrm{BiH}$ je, naime, na početku zadnje decenije XX vijeka važila za srednje ekonomski razvijenu zemlju Evrope. Pogotovo to nije slučaj sada, u prvoj deceniji XXI vijeka, kada je ekonomska snaga $\mathrm{BiH}$ znatno niža i dostiže tek oko $2 / 3$ ranijeg nivoa. Drugim riječima, $\mathrm{BiH}$ je, kao i većina ranijih socijalističkih zemalja, imala viši nivo fiskalnog opterećenja u odnosu na svoje realne ekonomske mogućnosti i u odnosu na realni fiskalni potencijal privrede. Rigidnost naslijeđene značajne javne potrošnje i dalje

1 Koristeći različita godišta navedene statistike OECD-a, može se konstatovati da se podaci za pojedine zemlje i pojedine godine razlikuju. U pitanju nije promjena metodologije, već detaljno naknadno utvrđivanje (provjeravanje) navedenog parametra. Ipak, osnovni zaključci ostaju. sector of goods and services. The high share of the public sector in these countries shows that the market mechanism is not able to always meet all economic functions and that it requires the presence of the public sector.

The different numbers hide different explanations of political, economic, social and other nature. In Japan, South Korea and the United States, for example, private corporations play a major role in the implementation of social security of employees, and the total households, and the level of fiscal burden in these three economically very powerful countries is relatively modest. In contrast, a country such as Sweden or Denmark, economically powerful countries with a long tradition of generous social protection of employees and the total households over the public sector, have a very high fiscal burden.

Fiscal burden (especially relative or effective) in $\mathrm{BiH}$ is very high, regardless of the shortcomings of its comparison with OECD countries. It is the result of, among other things, the fact that the place and role of the state in meeting the public needs (i.e. general and joint consumption) in $\mathrm{BiH}$, as one of the socialist countries, were more dominant than in most countries with market orientation. It should be noted that the level of fiscal burden was not in accordance with the then economic power of $\mathrm{BiH}$, which was more important than it is nowdays. At the beginning of the last decade of the twentieth century, $\mathrm{BiH}$ was regarded as medium developed country of Europe. It is not the case now, in the first decade of the XXI century, when the economic strength of $\mathrm{BiH}$ is significantly lower, reaching only about $2 / 3$ of the previous level. In other words, $\mathrm{BiH}$, like most of the former socialist countries, had a higher level of fiscal burden in relation to their real economic opportunities and in relation to the real fiscal potential of the economy. The rigidity of significant public spending legacy still survives

1 Using different years of these OECD statistics, it can be concluded that the data for each country and each year differ. It is not about a change of methodology, but rather a more detailed subsequent determination (verification) of the given parameter. Nevertheless, basic conclusions remain. 
u BiH opstaje i predstavlja jednu od ozbiljnijih razvojnih smetnji.

$\mathrm{U}$ rijetkim istraživanjima fiskalnog opterećenja u regionu ${ }^{2}$ (u poređenju 15 zemalja centralne i istočne Evrope), izračunato je da je $\mathrm{BiH}$ u 2012. godini sa $48 \%$ poreskog opterećenja u smom vrhu, odmah iza Mađarske $56 \%$ i Slovenije 50\%. Albanija 30\%, Turska $31 \%$ i Rumunija 32\% imaju znatno manje poresko opterećenje od $\mathrm{BiH}$. Rezultati svrstavaju BiH među zemlje iznad prosječnog globalnog fisklanog opterećenja. Među analiziranim zemljama veći udio poreza u BDP-u od $\mathrm{BiH}$ imaju samo Slovenija i Mađarska. Zemlje koje imaju najmanje udjele poreza u BDP-u su Albanija i Turska. U poređenju sa $\mathrm{BiH}$ njihov udio poreza u BDP-u je gotovo dvostruko manji. Zbog jednostavnosti izračuna i dostupnosti podataka, udio poreza u BDP-u je često korišten pokazatelj ocjene poreskog opterećenja pojedine zemlje. Međutim on zanemaruje čitav niz drugih aspekata koje valja uzeti u obzir kod ocjene poreskog opterećenja, a to su: struktura privrede, razvijenost institucionalnog sistema, nivo životnog standarda i sl. Iz toga razloga udio poreza u BDP-u može ponekad upućivati na pogrešne zaključke pogotovo ako se upoređuju zemlje različitog privrednog razvoja, strukture potražnje, institucionalnog kapaciteta, otvorenosti ekonomije, demografskih trendova i sl. Kako bi se uklonile eventualne manjkavosti ovog pokazatelja uputno je istražiti kakav je udio poreza u BDP-u u odnosu na poreski kapacitet ekonomije. Taj se omjer u literaturi naziva poreski napor, izračunava koliki je udio poreza u BDP-u u odnosu na poreski kapacitet tih zemalja. Zemlje koje imaju poresko opterećenje manje od poreskog kapacitetav imaju i prostora za povećanje poreza.

$\mathrm{Na}$ kraju, kako bi se dobila prava slika efektivnog fiskalnog opterećenja u $\mathrm{BiH}$, svakako bi trebalo (anketom) utvrditi efikasnost javnog sektora tj. javne uprave po pitanju trošenja prikupljenih poreza. Jer, kao što re-

2 Jedno od takvih je napisao G. Buturac, Država i ekonomija - gdje je Hrvatska?, u Zborniku radova sa 22. tradicionalnog savjetovanja „Ekonomska politika Hrvatske u 2015. godini““ održanog u Opatiji 12.-14. decembra 2014. in $\mathrm{BiH}$ and is one of the most serious developmental difficulties.

In the rare studies on the fiscal burden in the region $^{2}$ (compared to 15 countries in Central and Eastern Europe), it has been calculated that in 2012 , BiH with a $48 \%$ tax burden was placed in the very top, just behind Hungary and Slovenia, with $56 \%$ and $50 \%$, respectively. Albania, Turkey and Romania with $30 \%, 31 \%$ and $32 \%$, respectively, have a significantly lower tax burden from $\mathrm{BiH}$. Results classify $\mathrm{BiH}$ among the countries with above the average global fiscal burden. Among the analyzed countries, only Slovenia and Hungary have a greater share of taxes in GDP than BiH. Albania and Turkey are the countries that have the least share of taxes in GDP. Compared with $\mathrm{BiH}$ their share of taxes in GDP is almost twice smaller. For simplicity of calculation and availability of data, the share of taxes in GDP commonly used indicator of assessment of the tax burden of each country. However, it ignores a number of other aspects that should be taken into account when evaluating the tax burden, namely: the structure of the economy, the development of the institutional system, the level of living standards and the like. For this reason, the share of taxes in GDP can sometimes lead to wrong conclusions, especially when comparing the countries with different economic development, the structure of demand, institutional capacity, openness of the economy, demographic trends and the like. In order to remove any possible shortcomings in this indicator it is appropriate to investigate the share of taxes in GDP in relation to the tax capacity of the economy. This ratio is called the tax effort in the literature, and it calculates the share of taxes in GDP in relation to the tax capacity of these countries. Countries that have a tax burden less than the tax capacity have room to increase taxes.

Finally, in order to obtain a true picture of the effective fiscal burden in $\mathrm{BiH}$, it should be necessary to definitely determine (by survey) the efficiency of the public sector, i.e. the public administration in terms of spending the

2 One of these was written by G. Buturac, Država I ekonomija-gdje je Hrvatska? in Proceedings of the 22 traditional counseling "Croatian Economic Policy in 2015", held in Opatija, 12-14 December 2014. 
kosmo, javna uprava koja je racionalna i efikasna na strane javnih rashoda pomaže privredu i stanovništvo i na taj način relaksira fiskalni teret.

\section{SANDARDNI OKVIR FISKALNE ODRŽIVOSTI}

Iako se za ocjenjivanje fiskalne održivosti koristi nekoliko kriterija, centar uobičajeno predstavlja teoretski okvir koji se fokusira na to da li se u daljoj budućnosti može nastaviti s tekućom fiskalnom politikom bez ugrožavanja vladine solventnosti i nemogućnosti otplate javnog duga. Solventnost se ocijenjuje uzimajući u obzir sva tekuća i buduća sredstva i obaveze, procjenjujući sveobuhvatni bilans stanja javnog sektora. Ako su sredstva dovoljna za pokrivanje svih obaveza, stanje sadašnje fiskalne politike se smatra održivim. Zahtjevi za informacijama kod takvog pristupa su ogromni, i često ih je teško u potpunosti obezbijediti. Uži pristup fiskalne održivost koristi ograničenja konsolidovanog vladinog budžeta kao mjerilo prema kojem se određuje solventnost. U tom obimu literature, najjednostavniji pristup - racunovodstveni pristup - se fokusira na usklađenost fiskalne politike $\mathrm{s}$ određenim makroekonomskim ciljevima, održavajući postojeći omjer javnog duga i BDP-a konstantnim (ili u nekim slučajevima, dozvoljavajući povećanje tog omjera do nivoa koji se smatra podnošljivim i stabilizacijom nakon toga). Održivost se dostiže kada stopa rasta javnog duga ne prelazi stopu rasta nominalnog BDP-a, bar ne dugoročno. Iako ovaj pristup ne uključuje optimalnost fiskalnog deficita, ocjenjivanje usklađenosti s makroekonomskim ciljevima daje kreatorima politike odgovor na pitanje koliki bi deficit trebao biti. Ovaj analitički instrument se koristi za ocjenjivanje koliko je daleko sadašnja fiskalna politika od održivosti, koja se primarno definiše kao deficit potreban za stabilizaciju omjera duga . Analiza fiskalne održivosti počinje s ograničenjima budžeta $u$ jednom periodu i collected taxes. Because, as we said, the public administration that is rational and efficient to strain public expenditure helps economy and population and thus relaxes the fiscal burden.

\section{STANDARD FRAMEWORK OF FISCAL SUSTAINABILITY}

Although a number of criteria are used to assess the fiscal sustainability, usually the center is a theoretical framework that focuses on whether it is possible to continue in the distant future with the current fiscal policy without jeopardizing the government's solvency and inability to pay off the public debt. The solvency is assessed taking into account all current and future assets and liabilities, assessing the overall balance sheet of the public sector. If public funds are sufficient to cover all liabilities, the current state of fiscal policy is considered sustainable. Requests for information with such access are huge, and are often difficult to be fully provided. Narrower access to fiscal sustainability uses the limitations of the consolidated government budget as a paramount according to which solvency is determined. In this volume of literature, the simplest approach - Accounting approach focuses on the alignment of fiscal policy with certain macroeconomic objectives, while maintaining the existing ratio of public debt to GDP ratio constant (or in some cases, allowing for an increase in this ratio to levels that are considered acceptable with stabilization thereafter). Sustainability is achieved when the rate of growth of public debt does not exceed the growth rate of nominal GDP, at least not in the long run. Although this approach does not include the optimality of the fiscal deficit, the assessment of compliance with macroeconomic objectives gives policymakers the answer to the question of what the deficit should be. This analytical instrument is used for the evaluation of how far from sustainability the current fiscal policy is, which is primarily defined as the deficit required to stabilize debt ratios. Analysis of fiscal sustainability starts with the limits of the budget in a 
tri izvora javnog financiranja pored redovnog poreskog sistema: period and the three sources of public funding in addition to regular tax system:

$$
\mathrm{Gt}-\mathrm{Tt}=\mathrm{Bt}+\Delta \mathrm{Mt}=-\mathrm{St}+\mathrm{itBt}-1
$$

gde je Bt tržišna vrijednost vladinog duga u domaćoj valuti (neto od devizne rezerve), Gt i Tt vladini rashodi bez kamata i poreski prihodi, it je konačna kamata na vladin dug i Mt je nominalna novčana zaliha (monetarna baza). Primarni višak budžeta, St se definiše kao ukupni višak isključujući plaćanje kamata, ali uključujući vladinu emisiju novca. Jednačina (1) predstavlja tri različita načina kako se može finansirati budžetski deficit: ulaskom u dug (strani ili domaći), monetarnom ekspanzijom (emisija novca) i korištenjem devizne rezerve. U praksi, treći način se može koristiti samo u maloj mijeri i u kratkom vremenskom periodu.

Preračunavanjem jednačine (1) kao omera BDP-a, izražava se promijena u odnosu duga i BDP-a: where $\mathrm{Bt}$ is the market value of government debt in local currency (net of foreign exchange reserves), Gt and Tt are government expenditures excluding interest and tax revenues, it is the final interest rate on government debt and $\mathrm{Mt}$ is the nominal money supply (monetary base). The primary budget surplus, St is defined as the total surplus excluding interest payments but including government money issue. Equation (1) represents three different ways of financing the budget deficit: the entry in debt (foreign or domestic), monetary expansion (money emission) and the use of foreign exchange reserves. In practice, the third method can be used only at small extent, and in a short period of time.

Transforming this equation (1) as ratios of GDP, expresses changes in relation debt to GDP:

$$
\Delta \mathrm{bt}=\mathrm{bt}-\mathrm{bt}-1=|\mathrm{it}-(\pi+\mathrm{gt}+\pi \mathrm{tgt})| \mathrm{bt}-\mathrm{st}+|(\pi \mathrm{t}+\mathrm{gt}+\pi \mathrm{t} \mathrm{gt}) /(1+\mathrm{gt})(1+\pi \mathrm{t})| \mathrm{mt}
$$

gdje je b, m i s, omjeri javnog duga, novčane osnove i primarnog viška s BDP-om, dok je i konačna kamata na javni dug, p stopa inflacije $\mathrm{i} g$ realna stopa ekonomskog rasta. U racunovodstvenom okviru, primarni višak (ili deficit) se definiše kao odžriv, ako daje konstantan omjer duga i BDP-a, s obzirom na čvrste makroekonomske ciljeve i konstantne kamate. Stoga, se održiv omjer primarnog duga i BDP-a definiše postizanjem da Dbt, iznosi nula $\mathrm{i}$ ispuštanjem vremenskog elementa u jednačini (2):

$$
\mathrm{s}=|\mathrm{I}-(\pi+\mathrm{g}+\pi \mathrm{g})| \mathrm{b}+|(\pi+\mathrm{g}+\pi \mathrm{g}) /(1+\mathrm{g})(1+\pi)| \mathrm{m}
$$

U Bosni i Hercegovini, npr, monetarna i fiskalna politika se vodi u okviru ograničenja aranžmana valutnog odbora. U okviru valutnog odbora, vlada ne može uticati na stopu inflacije, p s obzirom da je ona određena stranom inflacijom kada je kurs fiksan. Vlada ta- where b, $\mathrm{m}$ i s, are public debt ratios, cash basis and the primary surplus to GDP, and $i$ is final public debt interest, $\pi$ is inflation rate and $\mathrm{g}$ is real rate of economic growth. In terms of accounting, the primary surplus (or deficit) is defined as sustainable if it gives the constant ratio of debt to GDP, given the strong macroeconomic objectives and constant interest. Therefore, the sustainable ratio of the primary sustainable debt to GDP is defined by achieving that $\Delta$ bt is zero and by dropping out the time element in the equation (2):

In Bosnia and Herzegovina, eg., monetary and fiscal policy is kept within the limits of the Currency Board Arrangements. In the CB context, the government can not influence the $\pi$ rate of inflation since it is determined by foreign inflation when the exchange rate is fixed. 
kođe nema uticaja na monetarnu osnovu, $\mathrm{m} \mathrm{s}$ obzirom na to da mora zadovoljiti tražnju za novcem da bi održala fiksni kurs. U osnovi postoje dva instrumenta politike: primarni deficit, s, i realna stopa rasta, g. Kreatori politike mogu poboljšati fiskalnu održivost osiguranjem adekvatnog primarnog viška i vođenjem šire politike koja podstiče rast.

Jednačina (3) je najjednostavniji okvir za procjenu doslednosti fiskalne politike. Međutim, analiza dosljednosti korištenjem jednačine (3) ima neka ograničenja. Na primjer, zanemaruje činjenicu da pored ograničenja solventnosti, zemlja može imati i ograničenje pozajmljivanja. Kreditori možda neće htjeti ili moći produžiti javni dug. Drugo, nema očiglednog elementa cirkularnosti. Neke od varijabli korištenih za izračunavanje indikatora solventnosti zavise istovremeno od stanja fiskalne solventnosti. To se jasno vidi $\mathrm{s}$ kamatama. Što su više kamate, potreban je veći primarni višak za stabilizaciju duga. Međutim, indikatori solventnosti takođe utiču na kamatne stope do mjere u kojoj izražavaju rizik od neplaćanja. Kao rezultat, indikatori solventnosti zavise od tih marži, a marže zavise od solventnosti. Ovaj tip cirkularnosti obično vodi ka višestrukoj ravnoteži. Paralelna analiza se može uraditi s drugim varijablama, kao što su kurs, kamata i stopa rasta. Nažalost, nema načina da se ova cirkularnost prekine i numeričke procjene treba posmatrati samo kao grube i približne.

\section{ZAKLJUČAK}

Uloga države u ekonomiji u $\mathrm{BiH}$ su uveliko pridonijeli procesi tranzicije, globalizacije, integracije i liberalizacije tržišta. Ekonomska kriza dodatno je podstakla rasprave o ulozi države u ekonomiji. Obilježje čitavog procesa je sve naglašenija potreba za prilagođavanjem i restrukturiranjem državnog sektora na način da se prihvate načela konkurentskog nadmetanja. Uz to, sve su izraženija očekivanja za kvalitetnijim angažmanom države, ne samo u područjima koje je ona dosada pokrivala, već i u nekim pot-
The government also has no impact on the $\mathrm{m}$ monetary base since it has to meet the demand for money in order to maintain a fixed exchange rate. There are basically two policy instruments: the primary deficit, s, and the real growth rate, g. Policy makers can improve the fiscal sustainability by providing adequate primary surplus and a broader policy that encourages growth.

Equation (3) is the simplest framework for assessing fiscal policy. However, consistency analysis by using equation (3) has some limitations. For example, it ignores the fact that in addition to solvency constraints, the country can have a borrowing limit. Creditors might not want or be able to extend the public debt. Second, there is no obvious element of circularity. Some of the variables used to calculate the indicators at the same time depend on the solvency of the state of fiscal solvency. This is clearly seen in the case of interest. The higher the interest is, the higher primary surplus to stabilize the debt is required. However, solvency indicators also affect the interest rate to the extent that they express the risk of non-payment. As a result, the indicators of solvency depend on these margins, and margins depend on the solvency. This type of circularity usually leads to multiple equilibria. A parallel analysis can be done with other variables, such as exchange rate, interest rates and growth rates. Unfortunately, there is no way that this circularity is interrupted and numerical estimates should be viewed only as rough and approximate.

\section{CONCLUSION}

The role of the state in the economy in $\mathrm{BiH}$ has greatly contributed to the process of transition, globalization, integration and market liberalization. The economic crisis has accentuated the debate on the role of the state in the economy. A characteristic feature of the whole process is the increasingly pronounced need for adjustment and restructuring of the public sector in a way to accept the principle of competitive bidding. In addition, expectations for quality involvement of the state are more and more pronounced, not only in areas which it has covered 
puno novim područjima. Ekonomska kriza prisutna zadnjih 6 godina u BiH dodatno se produbljuje povećavanjem državnih rashoda, budžetskog deficita i značajnim rastom zaduženosti. Sve veći dio proizvodnje je potrebno izdvajati za otplatu glavnice i kamata. Dosadašnje povećavanje zaduženosti nije ekonomski opravdano, jer nije dovelo do rasta investicija i bruto domaćeg proizvoda, već je bilo usmjeravano na povećavanje tekuće potrošnje. Gomilanje deficita i zaduženosti izaziva pad kreditnog rejtinga u inostranstvu, razvoj pesimističnih očekivanja i nesklonost ulaganjima. Istovremeno, uslovi velike zaduženosti nameću restriktivni karakter fiskalne politike (povećanje poreskog opterećenja!) što se u kratkom roku može negativno odraziti na ekonomsku aktivnost. Put izlaska iz recesije je u podsticanju investicione potrošnje i izvoza za što je između ostaloga potrebno poreski rasteretiti ekonomiju ili bar neke sektore i ciljane privredne aktivnosti. Zemlje koje imaju manje poresko opterećenje realizuju veće stope privrednog rasta. Pojedini rezultati analize se potvrđuju u percepciji građana o državnom sektoru u BiH. Traži se manji javni sektor, koji će biti jeftiniji i pružati znatno kvalitetniji nivo javnog dobra i usluge.

\section{LITERAURA}

Buturac, G. (2014). Država i ekonomija - gdje je Hrvatska?. U Zborniku Ekonomska politika Hrvatske u 2015. godini (str. 513-540). Opatija: Hrvatsko društvo ekonomista.

Dautbašić, I. (2004). Finansije i Finansijsko pravo. Sarajevo: Editio iuristica.

OECD. (2014). Revenue Statistics of OECD Member Countries 1965-2005. Paris: Autor.

Stojanović, A. i Raičević, B. (2013). Javne finansije. Sarajevo: Revicon. so far, but also in some completely new areas. The economic crisis present during last 6 years in $\mathrm{BiH}$ has further deepened by increasing government expenditure, budget deficit and a significant increase in indebtedness. An increasing part of the production is required to be allocated for repayment of the principal and interest. The previous increase in debt is not economically justified, because it has not led to investment and GDP growth, but it was directed to increase current spending. The accumulation of deficits and debt causes a drop in the credit rating abroad, the development of pessimistic expectations and reluctance to investments. At the same time, conditions of high indebtedness impose restrictive nature of fiscal policy (increasing the tax burden!) that in the short term can have negative effects on economic activity. The way out of the recession is in encouraging investment spending and exports, which inter alia requires the tax load relaxation of the economy, or at least of some targeted sectors and economic activities. Countries that have lower tax burden realize higher rates of economic growth. Some analysis results are confirmed in the perception of citizens about the public sector in $\mathrm{BiH}$. They seek a smaller public sector, which will be cheaper and provide significantly higher quality of public goods and services provision.

\section{LITERATURE}

Buturac, G. (2014). State and economy where is Croatia?. Ekonomska politika Hrvatske u 2015. godini (str. 513-540). Opatija: Hrvatsko društvo ekonomista.

Dautbašić, I. (2004). Finance and Financial Law. Sarajevo: Editio iuristica.

OECD. (2014). Revenue Statistics of OECD Member Countries 1965-2005. Paris: Autor.

Stojanović, A. i Raičević, B. (2013). Public finances. Sarajevo: Revicon. 
